Check for updates

Cite this: RSC Adv., 2018, 8, 26646

\title{
Hyperelatosides $A-E$, biphenyl ether glycosides from Hypericum elatoides, with neurotrophic activity $\dagger$
}

\author{
Xi-Tao Yan, (DD a Zhen An, ${ }^{\text {a }}$ Dan Tang, ${ }^{a}$ Guang-Rui Peng, ${ }^{\text {a }}$ Chen-Yu Cao, ${ }^{a}$ \\ Yuan-Zhen Xu, ${ }^{a}$ Chun-Huan Li, ${ }^{a}$ Pei-Liang Liu, ${ }^{b}$ Zai-Min Jiang ${ }^{\mathrm{C}}$ and Jin-Ming Gao (DD *a
}

Five new biphenyl ether glycosides, hyperelatosides $A-E(1-5)$, one new benzoate glycoside, hyperelatoside $F(6)$, along with nine known phenolic compounds (7-15), were isolated from the aerial parts of Hypericum elatoides. Their structures were elucidated by $1 \mathrm{D}$ and 2D NMR spectroscopy and HRESIMS, as well as chemical derivatization. This is the first report of the identification of biphenyl ether glycosides as plant metabolites and their possible biosynthetic pathway is proposed. Except for 3, the new phenolic metabolites exhibited significant neurotrophic activities to enhance nerve growth factor-induced neurite outgrowth in PC12 cells. In addition, the anti-neuroinflammatory and antioxidant activities of compounds 1-15 were preliminarily evaluated in vitro.

Received 21st June 2018

Accepted 5th July 2018

DOI: $10.1039 / \mathrm{c} 8 \mathrm{ra05322g}$

rsc.li/rsc-advances

our ongoing search for natural neurotrophic compounds with novel structures for potential neurodegenerative disease therapies, ${ }^{15} 15$ phenolic compounds including five new uncommon biphenyl ether glycosides named hyperelatosides A-E (1-5), one new benzoate glycoside named hyperelatoside $\mathrm{F}(\mathbf{6})$, and nine known, structurally related phenolic derivatives (7-15) were isolated from the $\mathrm{MeOH}$ extract of the aerial parts of $H$. elatoides (Fig. 1). Herein, we described the isolation and structural elucidation of these new phenolic metabolites, as well as the biological evaluation of their promoting effects on nerve growth factor (NGF)-induced neurite outgrowth in PC12 cells, inhibitory effects on lipopolysaccharide (LPS)-induced nitric oxide (NO) production in BV-2 cells, and 1,1-diphenyl-2-picrylhydrazyl (DPPH) free radical-scavenging capacities.

\section{Results and discussion}

anti-neurodegenerative, antioxidant, memory-enhancing, antiinflammatory, anticancer, anti-HIV, and antimicrobial activities. $^{7-13}$

Hypericum elatoides R. Keller is an herbaceous plant distributed in northwest China, especially in the western region of Shaanxi province. ${ }^{14}$ To date, there have been no phytochemical and biological studies on this plant. In the course of

\footnotetext{
${ }^{a}$ Shaanxi Key Laboratory of Natural Products \& Chemical Biology, College of Chemistry \& Pharmacy, Northwest A\&F University, Yangling 712100, China. E-mail: jinminggao@nwsuaf.edu.cn

${ }^{b}$ Key Laboratory of Resource Biology and Biotechnology in Western China, College of Life Sciences, Northwest University, Xi'an 710069, China

${ }^{\circ}$ College of Life Sciences, Northwest A\&F University, Yangling 712100, China

$\dagger$ Electronic supplementary information (ESI) available: 1D NMR, 2D NMR, and HRESIMS of 1-6; chemical structures of 7-15. See DOI: 10.1039/c8ra05322g
}

The $\mathrm{MeOH}$ extract of $H$. elatoides was subjected to liquid-liquid fractionation to afford a hexane-soluble fraction, an EtOAcsoluble fraction, and a $\mathrm{BuOH}$-soluble fraction. The active EtOAc fraction was separated by semipreparative reversed phase (RP) HPLC and column chromatography (CC) using silica gel, RP- $\mathrm{C}_{18}$, and Sephadex LH-20 to yield six new compounds (1-6) and nine known phenolic metabolites (7-15).

Compound 1 was isolated as a brown amorphous solid. Its molecular formula was determined to be $\mathrm{C}_{22} \mathrm{H}_{26} \mathrm{O}_{13}$ by HRESIMS $\left(m / z 521.1247[\mathrm{M}+\mathrm{Na}]^{+}\right.$, calcd for $\left.\mathrm{C}_{22} \mathrm{H}_{26} \mathrm{NaO}_{13}, 521.1271\right)$. The IR spectrum showed absorption bands at 3418 and $1701 \mathrm{~cm}^{-1}$ for hydroxyl and ester carbonyl groups, respectively. The low-field region of the ${ }^{1} \mathrm{H}$ NMR spectrum (measured in $\mathrm{CD}_{3} \mathrm{OD}$ ) exhibited two para-positional aromatic protons $\left[\delta_{\mathrm{H}} 7.44\right.$ $(1 \mathrm{H}, \mathrm{s}, \mathrm{H}-3)$ and $6.38(1 \mathrm{H}, \mathrm{s}, \mathrm{H}-6)]$ and two meta-coupled 


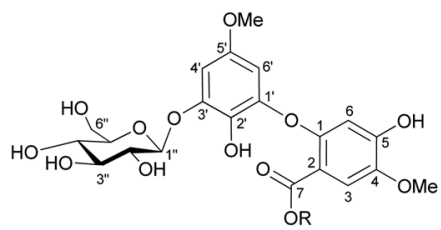

$1 \mathrm{R}=\mathrm{Me}$
$2 \mathrm{R}=\mathrm{H}$<smiles>COc1ccc(O)c(Oc2cc(OC)cc(OC3OC(O)C(O)C(O)C(O)O3)c2O)c1</smiles>

5<smiles>COc1cc(O)c2c(c1)Oc1cc(OC)c(OC)cc1C(=O)O2</smiles>

3

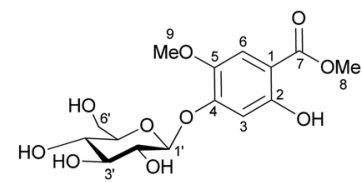

6<smiles>COc1cc(O)c(Oc2cc(OC)cc(O)c2OC2COC(O)C(O)C(O)C2O)c(OC)c1</smiles>

4

Fig. 1 Chemical structures of compounds 1-6.

aromatic protons $\left[\delta_{\mathrm{H}} 6.67\left(1 \mathrm{H}, \mathrm{d}, J=2.9 \mathrm{~Hz}, \mathrm{H}-4^{\prime}\right)\right.$ and $6.10(1 \mathrm{H}$, $\left.\left.\mathrm{d}, J=2.9 \mathrm{~Hz}, \mathrm{H}-6^{\prime}\right)\right]$ (Table 1), indicating the presence of a 1,2,4,5-tetrasubstituted (A-ring) and a 1,2,3,5-tetrasubstituted (B-ring) benzene rings, respectively. Further, the aliphatic region of the ${ }^{1} \mathrm{H}$ NMR spectrum showed signals of three methoxy groups $\left[\delta_{\mathrm{H}} 3.87(3 \mathrm{H}, \mathrm{s}), 3.78(3 \mathrm{H}, \mathrm{s})\right.$, and $\left.3.65(3 \mathrm{H}, \mathrm{s})\right]$ and a set of sugar protons $\left(\delta_{\mathrm{H}} 3.41-4.84\right)$. The ${ }^{13} \mathrm{C}$ NMR spectrum (Table 2) supported by DEPT experiments displayed signals of three methoxy carbons $\left(\delta_{\mathrm{C}} 57.1,56.3\right.$, and 52.5$)$, six characteristic glucopyranosyl carbons $\left(\delta_{\mathrm{C}} 104.2,78.6,77.7,75.0\right.$, 71.5 , and 62.6), an ester carbonyl carbon $\left(\delta_{\mathrm{C}} 167.9\right)$, and 12 aromatic carbons $\left(\delta_{\mathrm{C}} 100.5-154.3\right)$, including eight quaternary carbons and four methine carbons, corroborating the presence of two tetrasubstituted aromatic rings detected in the ${ }^{1} \mathrm{H}$ NMR spectrum. Furthermore, the ${ }^{1} \mathrm{H}$ NMR spectrum of $\mathbf{1}$, measured in DMSO- $d_{6}$, displayed the downfield signals of two hydroxyl groups at $\delta_{\mathrm{H}} 10.03$ and 8.03 (Table 1), which were attached to C5 position of A-ring and $\mathrm{C}-2^{\prime}$ position of B-ring based on the HMBC correlations from the hydroxyl proton at $\delta_{\mathrm{H}} 10.03$ to C-4, $\mathrm{C}-5$, and C-6 and from the hydroxyl proton at $\delta_{\mathrm{H}} 8.03$ to C- $1^{\prime}$, C$2^{\prime}$, and $\mathrm{C}-3^{\prime}$. In the HMBC spectrum, the correlations from the methoxy protons at $\delta_{\mathrm{H}} 3.78$ to the carbonyl carbon at $\delta_{\mathrm{C}} 167.9$ (C-

Table $1{ }^{1} \mathrm{H}$ NMR spectroscopic data $(500 \mathrm{MHz}, \delta$ in ppm, $\mathrm{J}$ in $\mathrm{Hz}$ ) for compounds $1-5$

\begin{tabular}{|c|c|c|c|c|c|c|c|}
\hline No. & $\mathbf{1}^{a}$ & $\mathbf{1}^{b}$ & $2^{a}$ & $3^{a}$ & $4^{a}$ & $4^{b}$ & $5^{a}$ \\
\hline 3 & $7.44, \mathrm{~s}$ & $7.32, \mathrm{~s}$ & $7.35, \mathrm{~s}$ & $7.34, \mathrm{~s}$ & $6.85, \mathrm{~d}(8.8)$ & $6.84, \mathrm{~d}(8.8)$ & $6.84, \mathrm{~d}(8.8)$ \\
\hline 4 & & & & & $6.59, \mathrm{dd}(8.8,2.9)$ & $6.58, \mathrm{dd}(8.8,3.0)$ & $6.56, \mathrm{dd}(8.8,2.9)$ \\
\hline $4^{\prime}$ & $6.67, \mathrm{~d}(2.9)$ & $6.64, \mathrm{~d}(2.9)$ & $6.68, \mathrm{~d}(2.8)$ & $6.72, \mathrm{~d}(2.9)$ & $6.24, \mathrm{~d}(2.9)$ & $6.19, \mathrm{~d}(2.9)$ & $6.67, \mathrm{~d}(2.9)$ \\
\hline $6^{\prime}$ & $6.10, \mathrm{~d}(2.9)$ & $6.14, \mathrm{~d}(2.9)$ & $6.33, \mathrm{~d}(2.8)$ & $6.54, \mathrm{~d}(2.9)$ & $5.91, \mathrm{~d}(2.9)$ & $5.74, \mathrm{~d}(2.9)$ & $6.17, \mathrm{~d}(2.9)$ \\
\hline $1^{\prime \prime}$ & $4.84, \mathrm{~d}(7.4)$ & $4.72, \mathrm{~d}(7.4)$ & $4.83, \mathrm{~d}(7.4)$ & $4.94, \mathrm{~d}(7.7)$ & $4.73, \mathrm{~d}(7.6)$ & $4.60, \mathrm{~d}(7.5)$ & $4.80, \mathrm{~d}(7.6)$ \\
\hline $4^{\prime \prime}$ & $3.41, \mathrm{~m}$ & $3.16, \mathrm{~m}$ & $3.39, \mathrm{~m}$ & $3.38, \mathrm{~m}$ & $3.42, \mathrm{~m}$ & $3.17, \mathrm{~m}$ & $3.41, \mathrm{~m}$ \\
\hline $5^{\prime \prime}$ & $3.45, \mathrm{~m}$ & $3.37, \mathrm{~m}$ & $3.44, \mathrm{~m}$ & $3.45, \mathrm{~m}$ & $3.25, \mathrm{~m}$ & $3.34, \mathrm{~m}$ & $3.44, \mathrm{~m}$ \\
\hline \multirow[t]{2}{*}{$6^{\prime \prime}$} & 3.71, dd $(12.1,5.8)$ & $\begin{array}{l}3.47, \mathrm{dd} \\
(11.8,5.9)\end{array}$ & $\begin{array}{l}3.70, \mathrm{dd} \\
(12.0,5.9)\end{array}$ & $\begin{array}{l}3.67, \mathrm{dd} \\
(12.1,5.9)\end{array}$ & $\begin{array}{l}3.69, \mathrm{dd} \\
(12.0,4.7)\end{array}$ & $\begin{array}{l}3.45, \mathrm{dd} \\
(11.7,5.8)\end{array}$ & $\begin{array}{l}3.71, \mathrm{dd} \\
(12.1,5.7)\end{array}$ \\
\hline & 3.92, dd $(12.1,2.1)$ & $3.75, \mathrm{~m}$ & $\begin{array}{l}3.91, \mathrm{dd} \\
(12.0,2.2)\end{array}$ & $\begin{array}{l}3.86, \mathrm{dd} \\
(12.1,2.2)\end{array}$ & $\begin{array}{l}3.77, \mathrm{dd} \\
(12.0,2.4)\end{array}$ & $3.62, \mathrm{~m}$ & $\begin{array}{l}3.91, \mathrm{dd} \\
(12.1,2.0)\end{array}$ \\
\hline $2-\mathrm{OH}$ & & & & & & $8.74, \mathrm{~s}$ & \\
\hline $5-\mathrm{OH}$ & & $10.03, \mathrm{~s}$ & & & & & \\
\hline $2^{\prime}-\mathrm{OH}$ & & $8.03, \mathrm{~s}$ & & & & & \\
\hline $3^{\prime}-\mathrm{OH}$ & & & & & & $9.08, \mathrm{br} \mathrm{s}$ & \\
\hline $2^{\prime \prime}-\mathrm{OH}$ & & $5.44, \mathrm{~d}(2.8)$ & & & & 6.05, br s & \\
\hline $3^{\prime \prime}-\mathrm{OH}$ & & 5.08, br s & & & & $5.12, \mathrm{~d}(4.4)$ & \\
\hline $4^{\prime \prime}-\mathrm{OH}$ & & $5.05, \mathrm{~d}(5.3)$ & & & & $4.99, \mathrm{~d}(4.6)$ & \\
\hline $6^{\prime \prime}-\mathrm{OH}$ & & $4.64, \mathrm{t}(5.5)$ & & & & $4.31, \mathrm{t}(5.7)$ & \\
\hline
\end{tabular}

${ }^{a}$ Date were recorded in $\mathrm{CD}_{3}$ OD. ${ }^{b}$ Date were recorded in DMSO- $d_{6}$. 
Table $2{ }^{13} \mathrm{C}$ NMR spectroscopic data (125 MHz, $\delta$ in ppm) for compounds $1-5$

\begin{tabular}{lccccccc}
\hline No. & $\mathbf{1}^{a}$ & $\mathbf{1}^{b}$ & $\mathbf{2}^{a}$ & $\mathbf{3}^{a}$ & $\mathbf{4}^{a}$ & $\mathbf{4}^{b}$ & $\mathbf{5}^{a}$ \\
\hline 1 & 153.9 & 152.5 & 152.9 & 158.0 & 146.0 & 143.9 & 146.4 \\
2 & 112.8 & 110.0 & 117.6 & 111.2 & 143.3 & 142.2 & 143.1 \\
3 & 115.3 & 114.4 & 115.0 & 115.6 & 118.4 & 117.2 & 118.2 \\
4 & 145.0 & 142.8 & 144.9 & 147.1 & 110.6 & 109.5 & 110.1 \\
5 & 153.7 & 151.9 & 151.8 & 155.8 & 155.0 & 152.4 & 155.0 \\
6 & 108.0 & 105.2 & 107.2 & 108.4 & 107.4 & 106.7 & 106.6 \\
7 & 167.9 & 165.0 & 172.8 & 166.4 & & & \\
$1^{\prime}$ & 147.0 & 143.9 & 146.8 & 154.0 & 152.1 & 150.9 & 146.8 \\
$2^{\prime}$ & 133.7 & 132.5 & 134.7 & 130.0 & 131.4 & 129.7 & 133.7 \\
$3^{\prime}$ & 148.4 & 147.0 & 148.6 & 150.8 & 153.1 & 151.4 & 148.5 \\
$4^{\prime}$ & 100.5 & 99.1 & 101.2 & 101.8 & 98.2 & 96.3 & 100.4 \\
$5^{\prime}$ & 154.3 & 151.8 & 154.0 & 159.2 & 158.8 & 156.2 & 154.4 \\
$6^{\prime}$ & 101.1 & 100.2 & 102.7 & 101.0 & 97.3 & 95.4 & 101.2 \\
$1^{\prime \prime}$ & 104.2 & 102.2 & 103.8 & 103.1 & 107.4 & 105.8 & 104.3 \\
$2^{\prime \prime}$ & 75.0 & 73.3 & 75.0 & 74.9 & 75.5 & 73.8 & 75.0 \\
$3^{\prime \prime}$ & 77.7 & 75.8 & 77.7 & 77.8 & 77.9 & 76.2 & 77.8 \\
$4^{\prime \prime}$ & 71.5 & 70.0 & 71.6 & 71.5 & 71.0 & 69.6 & 71.6 \\
$5^{\prime \prime}$ & 78.6 & 77.3 & 78.5 & 78.6 & 78.5 & 77.1 & 78.6 \\
$6^{\prime \prime}$ & 62.6 & 60.8 & 62.6 & 62.6 & 62.2 & 60.8 & 62.6 \\
4-OMe & 57.1 & 56.1 & 57.0 & 57.0 & & & \\
5-OMe & & & & & 56.4 & 55.2 & 56.4 \\
7-OMe & 52.5 & 51.5 & & & & & \\
$5^{\prime}$-OMe & 56.3 & 55.3 & 56.4 & 56.5 & 56.1 & 55.4 & 56.3 \\
${ }^{a}$ Date were recorded in CD ${ }_{3}$ OD. ${ }^{b}$ Date were recorded in DMSO- ${ }_{6}$. \\
\hline
\end{tabular}

7), from $\mathrm{H}-3\left(\delta_{\mathrm{H}} 7.44\right)$ to C-1 $\left(\delta_{\mathrm{C}} 153.9\right), \mathrm{C}-5\left(\delta_{\mathrm{C}} 153.7\right)$, and C-7 $\left(\delta_{\mathrm{C}}\right.$ $167.9)$, from $\mathrm{H}-6\left(\delta_{\mathrm{H}} 6.38\right)$ to $\mathrm{C}-2\left(\delta_{\mathrm{C}} 112.8\right)$ and $\mathrm{C}-4\left(\delta_{\mathrm{C}} 145.0\right)$, and from the methoxy protons at $\delta_{\mathrm{H}} 3.87$ to C-4 $\left(\delta_{\mathrm{C}} 145.0\right)$ (Fig. 2) suggested the presence of a methoxycarbonyl group and a methoxy group located at the C-2 and C- 4 positions of A-ring, respectively. In addition, the locations of a methoxy group at C$5^{\prime}$ and a sugar moiety at $\mathrm{C}-3^{\prime}$ of B-ring were established according to the HMBC correlations observed from the methoxy protons at $\delta_{\mathrm{H}} 3.65$ to $\mathrm{C}-5^{\prime}\left(\delta_{\mathrm{C}} 154.3\right)$ and from the anomeric proton at $\delta_{\mathrm{H}} 4.84\left(1 \mathrm{H}, \mathrm{d}, J=7.4 \mathrm{~Hz}, \mathrm{H}-1^{\prime \prime}\right)$ to $\mathrm{C}-3^{\prime}\left(\delta_{\mathrm{C}} 148.4\right)$, respectively. These two aromatic rings were bonded via an oxygen atom based on analysis of the chemical shifts of C-1 $\left(\delta_{\mathrm{C}}\right.$ 153.9) and $\mathrm{C}-1^{\prime}\left(\delta_{\mathrm{C}}\right.$ 147.0) together with the molecular formula. Acid hydrolysis followed by HPLC analysis after arylthiocarbamoyl-thiazolidine derivatization confirmed the characterization of a $\beta$-D-glucopyranosyl unit. Thus, the structure of 1 was elucidated as 2-(3-O- $\beta$-D-glucopyranosyl-2-hydroxy5-methoxyphenoxy)-4-hydroxy-5-methoxy-methylbenzoate and was named hyperelatoside A.

Compound 2 was obtained as a brown amorphous solid. Its molecular formula was deduced to be $\mathrm{C}_{21} \mathrm{H}_{24} \mathrm{O}_{13}$ by HRESIMS ion peak at $m / z$ 483.1150 $[\mathrm{M}-\mathrm{H}]^{-}$(calcd for $\mathrm{C}_{21} \mathrm{H}_{23} \mathrm{O}_{13}$, 483.1139). The ${ }^{1} \mathrm{H}$ and ${ }^{13} \mathrm{C}$ NMR data of 2 (Tables 1 and 2) showed similarity to those of $\mathbf{1}$, except for the lack of one methoxy signals as well as the chemical shift of C-7 $\left(\delta_{\mathrm{C}} 172.8 \mathrm{in}\right.$ 2 and $\delta_{\mathrm{C}} 167.9$ in 1). These observations indicated a carboxyl group in 2 instead of the methoxycarbonyl group in $\mathbf{1}$ at $\mathrm{C}-2$ position, which was supported by the molecular formula. In addition, the HMBC correlations of 2 (Fig. 2) confirmed the same connectivity as in $\mathbf{1}$. Therefore, the structure of 2 was determined as 2-(3-O- $\beta$-D-glucopyranosyl-2-hydroxy-5methoxyphenoxy)-4-hydroxy-5-methoxy benzoic acid and was given the name hyperelatoside $\mathrm{B}$.

Compound 3 was obtained as a brown amorphous solid. Its molecular formula was established as $\mathrm{C}_{21} \mathrm{H}_{22} \mathrm{O}_{12}$ by HRESIMS $\left(m / z 489.0998[\mathrm{M}+\mathrm{Na}]^{+}\right.$, calcd for $\left.\mathrm{C}_{21} \mathrm{H}_{22} \mathrm{NaO}_{12}, 489.1009\right)$, accounting for 11 degrees of unsaturation. The UV, IR, and NMR data of 3 were similar to those of 1 and 2 (Table 1), indicating that the structure of 3 is a biphenyl ether glycoside. The ${ }^{1} \mathrm{H}$ NMR spectrum of 3 revealed the presence of a 1,2,4,5-tetrasubstituted benzene ring, a 1,2,3,5-tetrasubstituted benzene ring, two methoxy groups, as well as a sugar moiety, which were consistent with the constituent units of 2. Similar HMBC correlations (Fig. 2) established that a sugar moiety, a carbonyl group, and two methoxy groups were located at the same

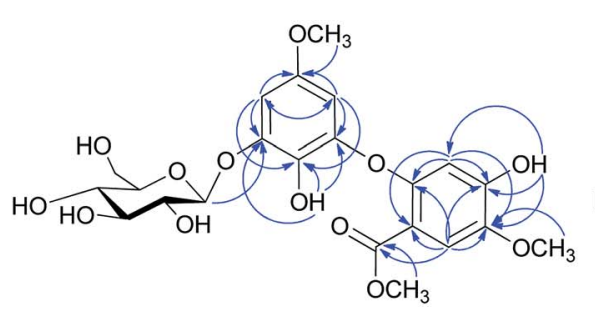

1

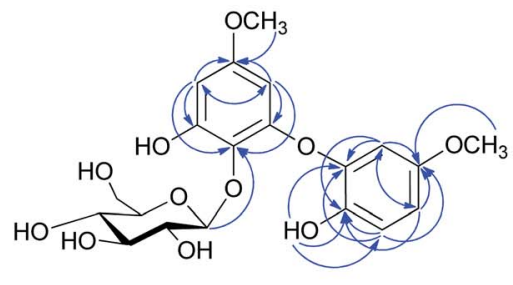

4

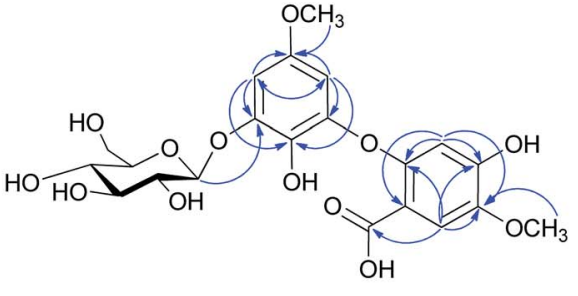

2

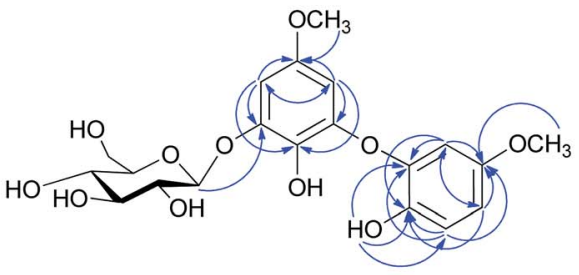

5

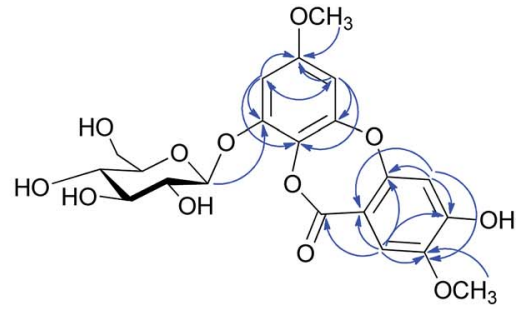

3

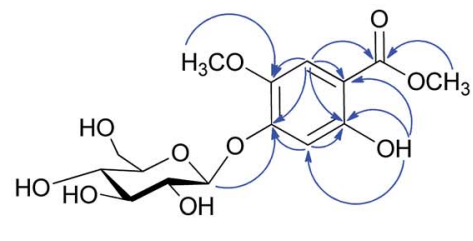

6

Fig. 2 Key HMBC (blue arrows) correlations of compounds 1-6. 
positions as 2. Compared with the chemical shifts of C-7 of 1 and 2 (Table 2), the appearance of an ester carbonyl carbon at $\delta_{\mathrm{C}}$ 166.4 in 3 suggested that an ester group presented between these two aromatic rings via the linkage of C-7-O-C-2', consistent with the 11 degrees of unsaturation required by the molecular formula. Acid hydrolysis result confirmed the sugar to be a $\beta$-D-glucopyranose. Hence, the structure of 3 was characterized as $2^{\prime}, 5$-dihydroxy- $4,5^{\prime}$-dimethoxy- $3^{\prime}$ - $O-\beta$ - - glucopyranosyl-2-carboxy-diphenyl ether $2,2^{\prime}$-lactone and was named hyperelatoside $\mathrm{C}$.

Compound 4 was obtained as a brown amorphous solid with a molecular formula of $\mathrm{C}_{20} \mathrm{H}_{24} \mathrm{O}_{11}$ based on HRESIMS $(\mathrm{m} / \mathrm{z}$ $463.1205[\mathrm{M}+\mathrm{Na}]^{+}$, calcd for $\left.\mathrm{C}_{20} \mathrm{H}_{24} \mathrm{NaO}_{11}, 463.1216\right)$. The ${ }^{1} \mathrm{H}$ NMR data of 4 (measured in $\mathrm{CD}_{3} \mathrm{OD}$, Table 1 ) exhibited a set of characteristic $\mathrm{ABX}$ aromatic protons at $\delta_{\mathrm{H}} 6.85(1 \mathrm{H}, \mathrm{d}, J=$ $8.8 \mathrm{~Hz}, \mathrm{H}-3), 6.59$ (1H, dd, $J=8.8,2.9 \mathrm{~Hz}, \mathrm{H}-4)$, and $6.46(1 \mathrm{H}, \mathrm{d}, J$ $=2.9 \mathrm{~Hz}, \mathrm{H}-6)$ and two meta-coupled aromatic protons at $\delta_{\mathrm{H}}$ $6.24\left(1 \mathrm{H}, \mathrm{d}, J=2.9 \mathrm{~Hz}, \mathrm{H}-4^{\prime}\right)$ and $5.91\left(1 \mathrm{H}, \mathrm{d}, J=2.9 \mathrm{~Hz}, \mathrm{H}-6^{\prime}\right)$, indicating the presence of a 1,2,4-trisubstituted (A-ring) and a 1,2,3,5-tetrasubstituted (B-ring) benzene rings, respectively. It also showed aliphatic signals for two methoxy groups $\left[\delta_{\mathrm{H}} 3.68\right.$ $(3 \mathrm{H}, \mathrm{s})$ and $3.65(3 \mathrm{H}, \mathrm{s})]$ and a set of sugar protons $\left(\delta_{\mathrm{H}} 3.25-\right.$ $4.73)$, including an anomeric proton at $\delta_{\mathrm{H}} 4.73(1 \mathrm{H}, \mathrm{d}, J=$ $\left.7.6 \mathrm{~Hz}, \mathrm{H}-1^{\prime \prime}\right)$. The ${ }^{13} \mathrm{C}$ NMR spectrum displayed signals for 12 aromatic carbons $\left(\delta_{\mathrm{C}} 97.3-158.8\right)$, two methoxy carbons $\left(\delta_{\mathrm{C}} 56.4\right.$ and 56.1), and a characteristic glucopyranosyl moiety $\left(\delta_{\mathrm{C}} 107.4\right.$, 78.5, 77.9, 75.5, 71.0, and 62.2) (Table 2). Acid hydrolysis result of 4 confirmed the sugar to be a $\beta$-D-glucopyranose. The assignment of signals corresponding to A-ring was based on the HMBC correlations from $\mathrm{H}-3\left(\delta_{\mathrm{H}} 6.85\right)$ to C-1 $\left(\delta_{\mathrm{C}} 146.0\right)$ and C-5 $\left(\delta_{\mathrm{C}} 155.0\right)$, from H-4 $\left(\delta_{\mathrm{H}} 6.59\right)$ to $\mathrm{C}-2\left(\delta_{\mathrm{C}} 143.3\right)$ and C-6 $\left(\delta_{\mathrm{C}} 107.4\right)$, and from $\mathrm{H}-6\left(\delta_{\mathrm{H}} 6.46\right)$ to $\mathrm{C}-2\left(\delta_{\mathrm{C}} 143.3\right)$ and $\mathrm{C}-4\left(\delta_{\mathrm{C}} 110.6\right)$ (Fig. 2). The methoxy protons at $\delta_{\mathrm{H}} 3.68$ exhibited a HMBC correlation to C-5 $\left(\delta_{\mathrm{C}} 155.0\right)$, which indicated the connection of a methoxy group at C-5 position of A-ring. Furthermore, the ${ }^{1} \mathrm{H}$ NMR spectrum of $\mathbf{4}$, measured in DMSO- $d_{6}$, displayed a hydroxyl proton signal at $\delta_{\mathrm{H}} 8.74(1 \mathrm{H}, \mathrm{s}, 2-\mathrm{OH})$, which showed HMBC correlations to $\mathrm{C}-1, \mathrm{C}-2$, and $\mathrm{C}-3$, supporting that a hydroxyl group was attached to $\mathrm{C}-2$ position of A-ring. Complete assignment of the ${ }^{1} \mathrm{H}$ and ${ }^{13} \mathrm{C}$ NMR data of B-ring was achieved by the HMBC correlations from $\mathrm{H}-4^{\prime}\left(\delta_{\mathrm{H}} 6.24\right)$ to $\mathrm{C}-2^{\prime}\left(\delta_{\mathrm{C}} 131.4\right), \mathrm{C}-3^{\prime}\left(\delta_{\mathrm{C}} 153.1\right), \mathrm{C}-5^{\prime}\left(\delta_{\mathrm{C}} 158.8\right)$, and C-6 ${ }^{\prime}\left(\delta_{\mathrm{C}} 97.3\right)$ and from $\mathrm{H}-6^{\prime}\left(\delta_{\mathrm{H}} 5.91\right)$ to $\mathrm{C}-1^{\prime}\left(\delta_{\mathrm{C}} 152.1\right), \mathrm{C}-2^{\prime}\left(\delta_{\mathrm{C}} 131.4\right), \mathrm{C}-4^{\prime}\left(\delta_{\mathrm{C}}\right.$ 98.2), and $\mathrm{C}-5^{\prime}\left(\delta_{\mathrm{C}}\right.$ 158.8) (Fig. 2). The HMBC correlations from the methoxy protons at $\delta_{\mathrm{H}} 3.65$ to $\mathrm{C}-5^{\prime}$ and from the anomeric proton at $\delta_{\mathrm{H}} 4.73$ to C-2' suggested the locations of a methoxy group at $\mathrm{C}-5^{\prime}$ and a $\beta$-D-glucopyranosyl moiety at $\mathrm{C}-2^{\prime}$, respectively. An ether linkage between C-1 $\left(\delta_{\mathrm{C}} 146.0\right)$ of A-ring and C- $1^{\prime}$ $\left(\delta_{\mathrm{C}} 152.1\right)$ of B-ring was then established due to their downfield chemical shifts and the molecular formula. Accordingly, compound 4 was identified as $2,3^{\prime}$-dihydroxy-5, $5^{\prime}$-dimethoxy-2' $O$ - $\beta$-D-glucopyranosyl-diphenyl ether and was named hyperelatoside $\mathrm{D}$.

Compound 5 was obtained as a brown amorphous solid. Its molecular formula was determined to be $\mathrm{C}_{20} \mathrm{H}_{24} \mathrm{O}_{11}$ based on a deprotonated ion peak at $m / z 439.1247[\mathrm{M}-\mathrm{H}]^{-}$(calcd for $\mathrm{C}_{20} \mathrm{H}_{23} \mathrm{O}_{11}, 439.1240$ ) in HRESIMS, identical to that found for compound 4. Moreover, the UV and IR spectra of $\mathbf{5}$ showed similar absorption bands to those of $\mathbf{4}$, indicating their similar structures. The ${ }^{1} \mathrm{H}$ and ${ }^{13} \mathrm{C}$ NMR data (Tables 1 and 2) of A-ring of $\mathbf{5}$ were almost superimposable to those of $\mathbf{4}$, but they differed in their B-ring, suggesting that the locations of the substituent groups on B-ring were different between 4 and 5. The glycosylation site at C-3' position of B-ring of $\mathbf{5}$ was inferred from an upfield shift of $\delta_{\mathrm{C}} 4.6 \mathrm{ppm}$ for C-3' (ipso-C) and downfield shifts of $\delta_{\mathrm{C}} 2.3 \mathrm{ppm}$ for $\mathrm{C}-2^{\prime}$ (ortho-C), $2.2 \mathrm{ppm}$ for $\mathrm{C}-4^{\prime}$ (ortho-C), and 3.9 ppm for C-6' (para-C) (Table 2). This was further supported by a HMBC cross-peak between the anomeric proton at $\delta_{\mathrm{H}} 4.80(\mathrm{H}-$ $\left.1^{\prime \prime}\right)$ and the corresponding aglycone carbon at $\delta_{\mathrm{C}} 148.5\left(\mathrm{C}-3^{\prime}\right)$ (Fig. 2). The $\beta$-D-glucopyranosyl moiety was determined by the same method as described for $\mathbf{1}$. Therefore, the structure of 5 was defined as $2,2^{\prime}$-dihydroxy-5, $5^{\prime}$-dimethoxy- $3^{\prime}$ - $O$ - $\beta$-D-glucopyranosyldiphenyl ether and was named hyperelatoside E.

Compound 6 was purified as white needles with a melting point of $220-222{ }^{\circ} \mathrm{C}$. The molecular formula, $\mathrm{C}_{15} \mathrm{H}_{20} \mathrm{O}_{10}$, was deduced from HRESIMS $\left(\mathrm{m} / \mathrm{z} 383.0946[\mathrm{M}+\mathrm{Na}]^{+}\right.$, calcd for $\left.\mathrm{C}_{15} \mathrm{H}_{20} \mathrm{NaO}_{10}, 383.0954\right)$. The IR spectrum showed absorption bands corresponding to a hydroxyl group $\left(3439 \mathrm{~cm}^{-1}\right)$ and a conjugated carbonyl group $\left(1666 \mathrm{~cm}^{-1}\right)$. The ${ }^{1} \mathrm{H}$ NMR spectrum exhibited signals attributable to one hydroxyl group $\left[\delta_{\mathrm{H}}\right.$ $10.46(1 \mathrm{H}, \mathrm{s}, 2-\mathrm{OH})]$, one 1,2,4,5-tetrasubstituted benzene ring $\left[\delta_{\mathrm{H}} 7.22(1 \mathrm{H}, \mathrm{s}, \mathrm{H}-6)\right.$ and $\left.6.71(1 \mathrm{H}, \mathrm{s}, \mathrm{H}-3)\right]$, one anomeric proton at $\delta_{\mathrm{H}} 5.04\left(1 \mathrm{H}, \mathrm{d}, J=7.2 \mathrm{~Hz}, \mathrm{H}-1^{\prime}\right)$, and two methoxy groups $\left[\delta_{\mathrm{H}}\right.$ $3.88(3 \mathrm{H}, \mathrm{s}, \mathrm{H}-8)$ and $3.73(3 \mathrm{H}, \mathrm{s}, \mathrm{H}-9)]$ (Table 3$)$. The ${ }^{13} \mathrm{C}$ NMR spectrum displayed 15 carbon resonances, which were classified as an ester carbonyl carbon $\left(\delta_{\mathrm{C}} 169.3\right)$, six aromatic carbons $\left(\delta_{\mathrm{C}} 103.5-156.6\right)$, a characteristic glucopyranosyl moiety $\left(\delta_{\mathrm{C}}\right.$ $99.4,77.1,76.7,73.0,69.5$, and 60.6), and two methoxy carbons $\left(\delta_{\mathrm{C}} 56.1\right.$ and 52.3 ) (Table 3 ). The $\beta$-D-glucopyranosyl unit was verified by the same method as described for 1. In the HMBC spectrum of 6 , the methoxy protons at $\delta_{\mathrm{H}} 3.88(\mathrm{H}-8)$ exhibited a correlation with the carbonyl carbon at $\delta_{\mathrm{C}} 169.3$ (C-7), which suggested that 6 is a derivative of methyl benzoate. The key HMBC correlations from $\mathrm{H}-6\left(\delta_{\mathrm{H}} 7.22\right)$ to $\mathrm{C}-1\left(\delta_{\mathrm{C}} 104.1\right), \mathrm{C}-2\left(\delta_{\mathrm{C}}\right.$ 156.6), C-4 $\left(\delta_{\mathrm{C}} 153.3\right), \mathrm{C}-5\left(\delta_{\mathrm{C}} 142.1\right)$, and C-7 $\left(\delta_{\mathrm{C}} 169.3\right)$, from the hydroxyl proton at $\delta_{\mathrm{H}} 10.46$ to $\mathrm{C}-1\left(\delta_{\mathrm{C}} 104.1\right), \mathrm{C}-2\left(\delta_{\mathrm{C}} 156.6\right)$, and $\mathrm{C}-3\left(\delta_{\mathrm{C}} 103.5\right)$, and from the methoxy protons at $\delta_{\mathrm{H}} 3.73(\mathrm{H}-9)$ to C-5 $\left(\delta_{\mathrm{C}}\right.$ 142.1) (Fig. 2), indicated the locations of a hydroxyl group and a methoxy group at $\mathrm{C}-2$ and $\mathrm{C}-5$, respectively. In addition, the anomeric proton at $\delta_{\mathrm{H}} 5.04\left(\mathrm{H}-1^{\prime}\right)$ exhibited a HMBC correlation with C-4 $\left(\delta_{\mathrm{C}}\right.$ 153.3), indicating that the glucopyranosyl moiety was attached to C-4 position. Thus, compound 6 was assigned as 4- $O$ - $\beta$-D-glucopyranosyl-2-hydroxy5-methoxy-methylbenzoate and was named hyperelatoside $\mathrm{F}$.

The remaining compounds were elucidated on the basis of NMR and ESIMS data analysis as well as by comparison with literature data. They were identified as 3,5-dihydroxy-4methoxyxanthone (7), ${ }^{16}$ 1,5,6-trihydroxy-7-methoxyxanthone (8), ${ }^{17}$ 1,3,7-trihydroxy-2-(2-hydroxy-3-methyl-3-butenyl)-xanthone $(9),{ }^{18} \quad 2,4$-dihydroxy-3-methyl-6- $O$ - $\beta$-D-glucopyranosyl benzophenone (10), ${ }^{19}$ garcimangosone $\mathrm{D} \quad(\mathbf{1 1}),{ }^{20}$ 1-(2-methylbutyryl)phloroglucinol-glucopyranoside (12), ${ }^{21}$ quercetin $3-O-\alpha$-L-rhamnopyranoside (13), ${ }^{22}$ quercetin 3-O- $\beta$-D-galactopyranoside (14), ${ }^{23}$ and kaempferol 3-O- $\alpha$-L-rhamnopyranoside $(\mathbf{1 5})^{\mathbf{2 4}}$ (Fig. S54, ESI $\dagger$ ). 
Table $3{ }^{1} \mathrm{H}$ NMR $(500 \mathrm{MHz})$ and ${ }^{13} \mathrm{C}$ NMR (125 MHz) spectroscopic data for compound 6 (DMSO- $d_{6}$ )

\begin{tabular}{|c|c|c|}
\hline No. & $\delta_{\mathrm{H}}(J$ in $\mathrm{Hz})$ & $\delta_{\mathrm{C}}$ \\
\hline 1 & & 104.1 \\
\hline 2 & & 156.6 \\
\hline 3 & $6.71, \mathrm{~s}$ & 103.5 \\
\hline 4 & & 153.3 \\
\hline 5 & & 142.1 \\
\hline 6 & $7.22, \mathrm{~s}$ & 111.5 \\
\hline 7 & & 169.3 \\
\hline 8 & $3.88, \mathrm{~s}$ & 52.3 \\
\hline 9 & $3.73, \mathrm{~s}$ & 56.1 \\
\hline \multicolumn{3}{|l|}{$4 a$} \\
\hline \multicolumn{3}{|l|}{$4 \mathrm{~b}$} \\
\hline \multicolumn{3}{|l|}{$8 \mathrm{a}$} \\
\hline \multicolumn{3}{|l|}{$9 a$} \\
\hline $1^{\prime}$ & $5.04, \mathrm{~d}(7.2)$ & 99.4 \\
\hline $2^{\prime}$ & $3.26, \mathrm{~m}$ & 73.0 \\
\hline $3^{\prime}$ & $3.28, \mathrm{~m}$ & 76.7 \\
\hline $4^{\prime}$ & $3.16, \mathrm{~m}$ & 69.5 \\
\hline $5^{\prime}$ & $3.39, \mathrm{~m}$ & 77.1 \\
\hline \multirow[t]{2}{*}{$6^{\prime}$} & 3.45, dd $(11.7,5.2)$ & 60.6 \\
\hline & 3.66, dd $(11.7,6.0)$ & \\
\hline \multicolumn{3}{|l|}{ 1-OH } \\
\hline $2-\mathrm{OH}$ & $10.46, \mathrm{~s}$ & \\
\hline \multicolumn{3}{|l|}{$7-\mathrm{OH}$} \\
\hline $2^{\prime}-\mathrm{OH}$ & $5.34, \mathrm{~d}(5.1)$ & \\
\hline $3^{\prime}-\mathrm{OH}$ & $5.13, \mathrm{~d}(4.6)$ & \\
\hline $4^{\prime}-\mathrm{OH}$ & $5.06, \mathrm{~d}(5.3)$ & \\
\hline $6^{\prime}-\mathrm{OH}$ & $4.58, \mathrm{t}(5.6)$ & \\
\hline
\end{tabular}

Among them, compounds 7, 10, and $\mathbf{1 2}$ were isolated from the genus Hypericum for the first time.

Naturally occurring biphenyl ethers have been reported to be in some fungi in recent years, especially Aspergillus species, ${ }^{25}$ but are rarely found in plants. ${ }^{26}$ In fungi, these kinds of compounds are formed biosynthetically from the anthraquinone emodin, via sulochrin, and the grisandienes such as geodin was previously reported. ${ }^{27}$ However, these intermediates of desmethylsulochrin, sulochrin, dihydrogeodin, and geodin are rarely as the plant metabolites. Given the isolation of benzoic acid derivatives ( 6 and 12), benzophenones (10 and 11), and xanthones (7-9) from $H$. elatoides, the possible biosynthetic pathway of hyperelatosides A-E (1-5) is proposed in Scheme 1. The key step of this pathway is the xanthone ring cleavage reaction to form biphenyl ether skeleton, the immediate precursors of which may be 1,3,6,7- and 1,3,5,8-tetrahydroxyxanthones. Although the formation of biphenyl ethers from xanthones catalyzed by an enzyme system involving an oxygenase, has not yet detected in plants, the similar reaction has been observed in the biosynthetic studies of biphenyl ethers from anthraquinones in fungi. An anthraquinone ring cleavage enzyme, named questin oxygenase, was found in the cell-free extract of Aspergillus terreus and the reaction mechanism underlying the ring cleavage of anthraquinone is likely to be a chemical Baeyer-Villiger oxidation and hydrolysis of the formed lactone intermediate. ${ }^{27,28}$ This suggested that the same type of enzymes as questin oxygenase may be involved in the formation of biphenyl ethers from xanthones in $H$. elatoides.
Xanthones and benzophenones are two major constituents of the plants of the genus Hypericum. ${ }^{1 \mathrm{e}}$ The biosynthesis of xanthone products has been studied in $H$. androsaemum, $H$. calycinum, and $H$. perforatum. ${ }^{29}$ 2,3',4,6-Tetrahydroxybenzophenone, which is formed from benzoic acid by the condensation of one benzoyl CoA and three malonyl CoA units catalyzed by benzophenone synthase, is cyclized regioselectively to yield either 1,3,7- or 1,3,5-trihydroxyxanthone, which is then regioselectively hydroxylated to $1,3,6,7$ - or 1,3,5,8-tetrahydroxyxanthone. ${ }^{30}$ Subsequent xanthone ring cleavage reaction gives the biphenyl ether skeleton, which may generate the structures of 1-5 via enzymatic reactions of decarboxylation, $O$-methylation using $S$-adenosylmethionine (SAM), and glycosylation.

The neurotrophic activities of new compounds 1-6 were investigated in terms of their ability to enhance NGF-induced neurite outgrowth using rat pheochromocytoma (PC12) cells as a model system of neuronal differentiation. Fig. 3 showed that, relative to the NGF control (100\%), compounds 1, 2, and 46 exerted a significant increase in neurite-bearing cells at $1 \mu \mathrm{M}$. In particular, the percentages of neurite-bearing cells for cells treated with hyperelatosides B (2) and D (4) in the presence of $\mathrm{NGF}\left(20 \mathrm{ng} \mathrm{mL^{-1 }}\right)$ reached up to $192.78 \pm 17.71 \%$ and $228.70 \pm$ $12.51 \%$ relative to the NGF control, respectively. Interestingly, among the biphenyl ether glycosides (1-5), only 3 had no effect on NGF-medicated neurite outgrowth in PC12 cells at $1 \mu \mathrm{M}$, suggesting that the presence of a carboxyl or hydroxyl group at C-2 position of A-ring may be responsible for the neurotrophic activity. Compound $\mathbf{2}$ showed much stronger activity than $\mathbf{1}$, indicating that attachment of an active hydrogen atom to the $\mathrm{O}$ 7 position of the carboxyl group could significantly improve this activity than attachment of a methyl group to 0-7 position.

Neuroinflammation has been typically involved in the pathology of neurodegenerative diseases such as Alzheimer's disease and Parkinson's disease. Therefore, the inhibitory effects of compounds 1-15 on LPS-stimulated NO production in BV-2 microglial cells were investigated to establish their antineuroinflammatory activities. As shown in Fig. 4, compounds 5,8 , and 14 exhibited inhibitory effects against NO production in BV-2 cells at $25 \mu \mathrm{M}$. In order to investigate whether the inhibitory activities of the active compounds were due to their cytotoxicity towards BV-2 cells, the effects of compounds 5, 8, and 14 on cell proliferation/viability were measured by 3-(4,5dimethylthiazole-2-yl)-2,5-diphenyltetrazolium bromide (MTT) method. Of these, compounds 5 and $\mathbf{8}$ showed no cytotoxicity with LPS treatment for $24 \mathrm{~h}$.

In addition, severe oxidative stress has been also implicated in the pathogenesis of neurodegenerative diseases. The antioxidant activities of compounds 1-15 were preliminarily evaluated for their DPPH free radical scavenging properties at 1, 5, $10,25,50$, and $100 \mu \mathrm{M}$ using ascorbic acid as the positive control $\left(\mathrm{IC}_{50}=12.45 \pm 0.51 \mu \mathrm{M}\right)$. The result showed that compound 14 exhibited the most significant DPPH radical scavenging activity with $\mathrm{IC}_{50}$ value of $11.22 \pm 0.38 \mu \mathrm{M}$ (Table 4 ), which showed stronger antioxidant activity than the positive control. Its potent activity may be due to the presence of two hydroxyl groups at C-3 and C-4 positions of the aromatic ring, which agrees with previous studies. ${ }^{31}$ Moreover, compounds 2, 


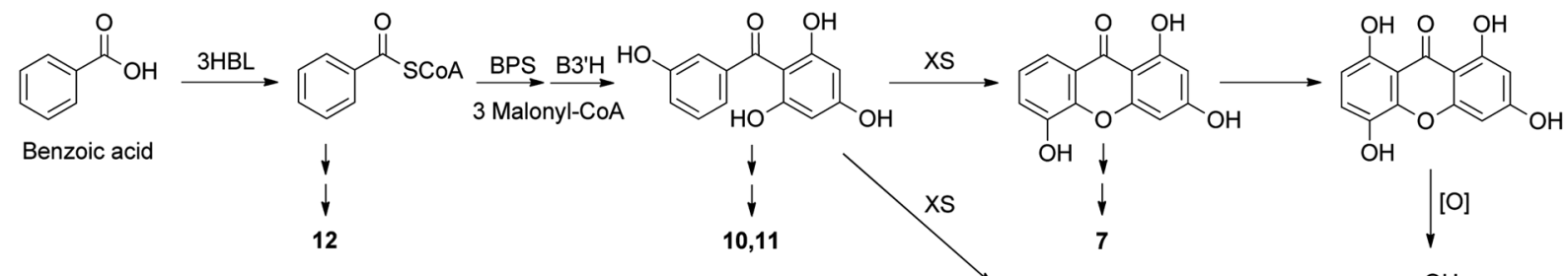<smiles>CC(C)CC(C)C(C)C(C)C</smiles><smiles>O=C1Oc2c(O)cc(O)cc2Oc2c(O)ccc(O)c21</smiles><smiles>O=C(O)c1cc(O)c(O)cc1Oc1cc(O)cc(O)c1O</smiles><smiles>COc1cc(OC)c2c(c1)Oc1cc(OC)c(OC)cc1C(=O)O2</smiles><smiles>COc1ccc(O)c(Oc2cc(OC)cc(OC)c2OC2CCCCC2)c1</smiles>

4

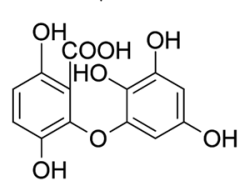<smiles>COc1cc(OC)c(O)c(Oc2cc(O)c(OC)cc2Oc2c(OC)cc(OC)cc2C(=O)O)c1</smiles>
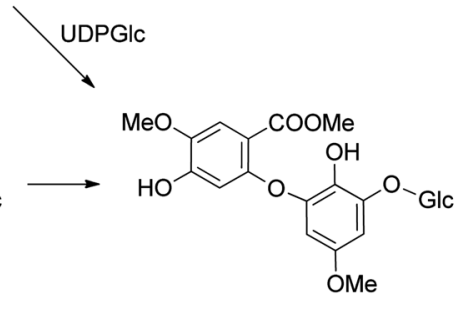

1

Scheme 1 Proposed biosynthetic pathway for biphenyl ether glycosides identified from H. elatoides (3HBL, 3-hydroxybenzoate:CoA ligase; BPS, benzophenone synthase; B3'H, benzophenone $3^{\prime}$-hydroxylase; XS, xanthone synthase; $\mathrm{X} 6 \mathrm{H}$, xanthone 6-hydroxylase; SAM, S-adenosylmethionine; UDPGlc, uridine diphosphate glucose; Glc, glucopyranosyl unit).

4, 5, 8, and 13 exhibited moderate antioxidant activities. The remaining compounds were proved to have weak or no DPPH radical scavenging activities at concentrations of 1-100 $\mu \mathrm{M}$.

\section{Experimental section}

\section{General experimental procedures}

Optical rotations were measured with an Auton Paar MCP300 automatic polarimeter (Anton Paar, Graz, Austria). The UV spectra were obtained on a Thermo Scientific Evolution-300 UVvisible spectrophotometer (Thermo Fisher Scientific, Waltham, MA, USA). The IR spectra were recorded on a Bruker Tensor 27 FT-IR spectrometer with $\mathrm{KBr}$ pellets (Bruker, Billerica, MA, USA). The NMR spectra were obtained on a Bruker Avance III 500 spectrometer (Bruker, Billerica, MA, USA). HRESIMS were recorded on an $\mathrm{AB}$ Triple $\mathrm{TOF} \otimes 4600$ mass spectrometer ( $\mathrm{AB}$ SCIEX, Redwood City, CA, USA). Semipreparative HPLC was performed with a system consisting of LC-20AP pumps (Shimadzu, Kyoto, Japan) and a SPD-20A UV/vis detector (Shimadzu, Kyoto, Japan) equipped with YMC Packed $\mathrm{C}_{18}$ columns (5 $\mu \mathrm{m}$, $250 \times 10.0 \mathrm{~mm}$ and $150 \times 4.6 \mathrm{~mm}$, YMC Co., Ltd., Kyoto, Japan). Column chromatography was performed on silica gel (100-200 and 200-300 mesh, Qingdao Marine Chemical Ltd., Qingdao, China), RP-C $_{18}$ resins (YMC Gel ODS-A-HG, $50 \mu \mathrm{m}$ particle size, YMC Co., Ltd., Kyoto, Japan), and Sephadex LH-20 (Pharmacia Fine Chemicals, Uppsala, Sweden). Thin-layer chromatography (TLC) was performed on silica gel $60 \mathrm{~F}_{254}$ and RP-18 $\mathrm{F}_{254 \mathrm{~S}}$ plates (Merck KGaA, Darmstadt, Germany). Fractions were monitored by TLC, and spots were visualized by UV light (254 and $365 \mathrm{~nm}$ ) and spraying with $10 \% \mathrm{H}_{2} \mathrm{SO}_{4}$ in ethanol, followed by heating. The purity of obtained compounds were determined by analysis of ${ }^{1} \mathrm{H}$ NMR spectra and HPLC. Horse serum (HS), fetal bovine serum (FBS), and Dulbecco's modified Eagle medium (DMEM) were purchased from Gibco (Thermo Fisher Scientific, Bremen, Germany). NGF, authentic sugars, ascorbic acid, quercetin, dimethylsulfoxide (DMSO), DPPH, the growth substrate poly-L-lysine, and nutrient mixture F-12 (Ham) were purchased from Sigma-Aldrich (Merck KGaA, Darmstadt, Germany).

\section{Plant material}

The aerial parts of $H$. elatoides were collected in Dongjue Mountain, Qishan County, Shaanxi Province, China, in September 2016. The plant was identified by Professor Zai-Min Jiang, College of Life Sciences, Northwest A\&F University. A voucher specimen (Jiang 1043) was deposited in the herbarium of Northwest A\&F University (WUK), Yangling, China. 
A

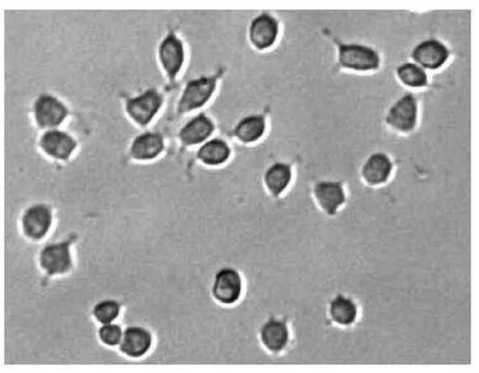

DMSO control

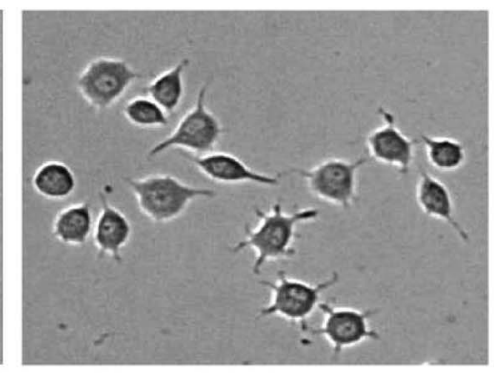

NGF control

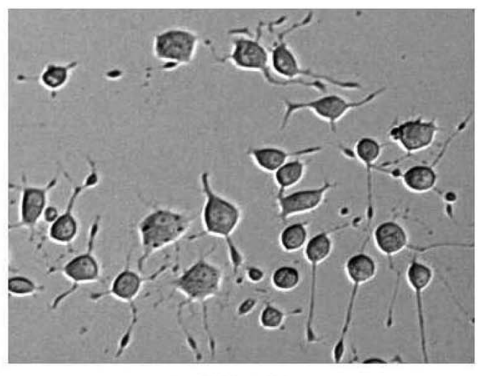

$\mathrm{NGF}+4$

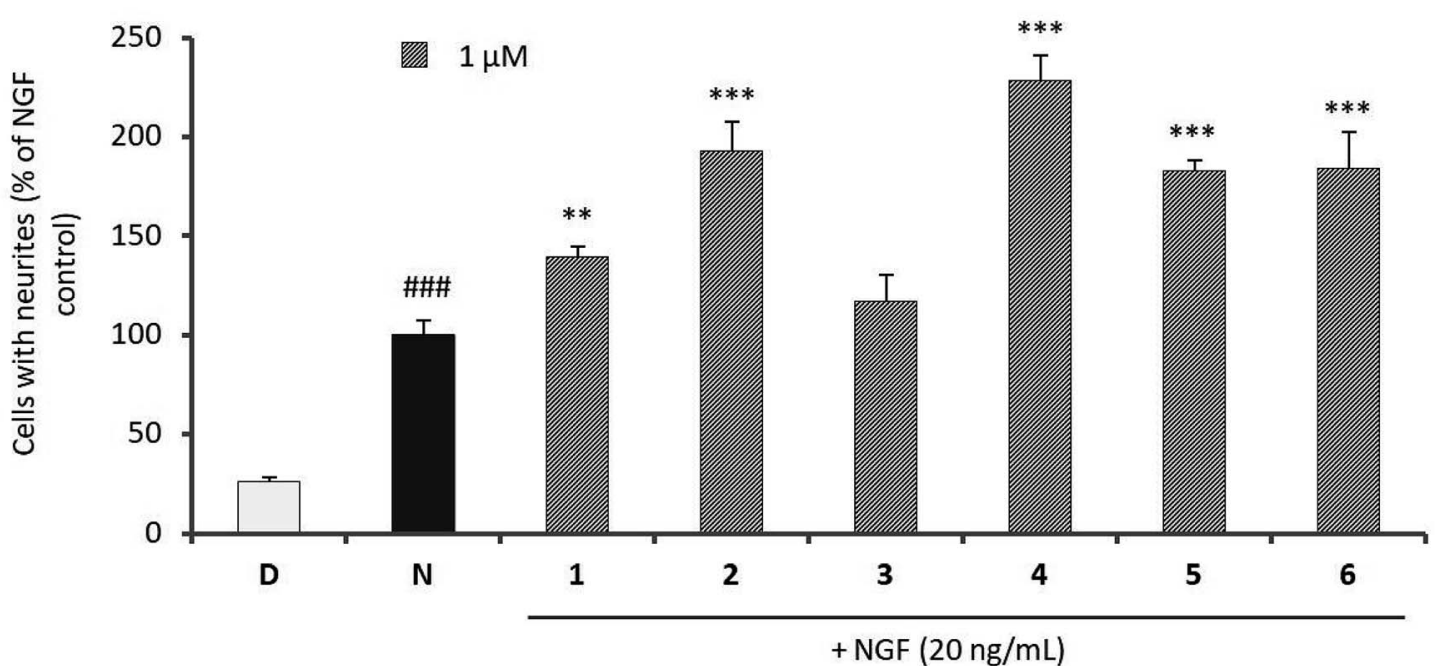

Fig. 3 Effects of compounds 1-6 on neurite outgrowth in PC12 cells. (A) Morphological changes of PC12 cells treated with $0.1 \%$ DMSO, NGF (20 $\left.\mathrm{ng} \mathrm{mL} \mathrm{mL}^{-1}\right)$, and NGF $\left(20 \mathrm{ng} \mathrm{mL}^{-1}\right)+4(1.0 \mu \mathrm{M})$ were visualized under light microphotography. The cells treated with 4 served as a representative example to demonstrate the enhancement of neurite outgrowth in the presence of NGF. (B) Neurite-bearing cells were quantitatively analyzed as described in measurement of neurite outgrowth. Data are expressed as percentages of the value of NGF-treated cells (means \pm standard deviations, $n=3$ ) (D, 0.1\% DMSO, control; N, $20 \mathrm{ng} \mathrm{mL}^{-1} \mathrm{NGF}$, positive control; $\# \# \# p<0.001 \mathrm{vs}$. control; $* p<0.05, * * p<0.01, * * * p<0.001 \mathrm{vs}$. NGF control).

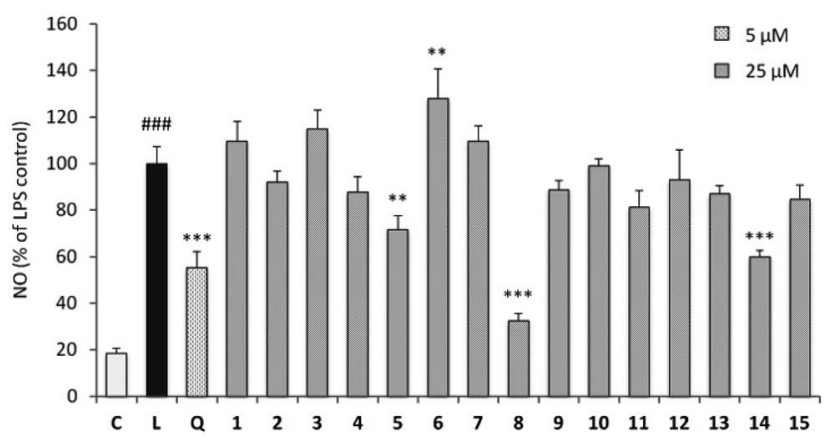

Fig. 4 Effects of compounds 1-15 on LPS-induced NO production in BV-2 microglial cells. Data are expressed as percentages of the value obtained with LPS-treated cells. (C, untreated control, 0.1\% DMSO; L, LPS-treated control; $Q$, quercetin, $5 \mu \mathrm{M}$, positive control; ${ }^{\# \#} p<0.001$ compared with control group, $* * p<0.01, * * * p<0.001$ compared with LPS group).

\section{Extraction and isolation}

The aerial parts $(1.3 \mathrm{~kg})$ of $H$. elatoides were dried in shade, cut into small pieces, and extracted three times (each for $8 \mathrm{~h}$ ) with $12 \mathrm{~L}$ of $\mathrm{MeOH}$ under reflux conditions $\left(55^{\circ} \mathrm{C}\right)$. After filtration and evaporation in vacuo, the obtained extract (334.8 g) was suspended in distilled water ( $3 \mathrm{~L})$ and partitioned successively with $n$-hexane $(3 \mathrm{~L} \times 3)$, EtOAc $(3 \mathrm{~L} \times 3)$, and $n$-BuOH $(3 \mathrm{~L} \times 3)$ to yield a hexane-soluble fraction (55.6 g), an EtOAc-soluble fraction (49.2 g), and a $\mathrm{BuOH}$-soluble fraction (71.0 g), respectively. The EtOAc fraction was subjected to silica gel $\mathrm{CC}$ and eluted with a gradient of $\mathrm{CH}_{2} \mathrm{Cl}_{2} / \mathrm{MeOH}(100: 1$ to $2: 1)$ to yield fifteen fractions (E1-E15). Fr. E3 was further subjected to RP-C 18 $\mathrm{CC}$ (acetone- $\left.\mathrm{H}_{2} \mathrm{O}, 1: 6\right)$ to give ten subfractions (E3.1-E3.10). Fr. E3.5 was subjected to silica gel $\mathrm{CC}\left(\mathrm{CHCl}_{3}-\mathrm{MeOH}, 100: 1\right)$ to afford compound 7 (63.1 mg). Fr. E6 was subjected to silica gel $\mathrm{CC}\left(\mathrm{CH}_{2} \mathrm{Cl}_{2}-\mathrm{MeOH}, 30: 1\right.$ to $\left.20: 1\right)$ to yield eight subfractions (E6.1-E6.8). Fr. E6.3 was purified on a $\mathrm{RP}^{-\mathrm{C}_{18}}$ column (MeOH$\left.\mathrm{H}_{2} \mathrm{O}, 3: 1\right)$ to yield compound $8(26.5 \mathrm{mg})$. Fr. E6.4 was purified on a RP-C ${ }_{18}$ column (acetone-MeOH, $1: 5$ ) to yield compound 9 $(24.6 \mathrm{mg})$. Fr. E9 was subjected to silica gel CC and eluted with a gradient of $\mathrm{CHCl}_{3}-\mathrm{MeOH}-\mathrm{H}_{2} \mathrm{O}(15: 1: 0.05$ to $4: 1: 0.1)$ to yield eight fractions (E9.1-E9.8). Fr. E9.4 was further separated by $\mathrm{RP}^{-\mathrm{C}_{18}} \mathrm{CC}\left(\mathrm{MeOH}-\mathrm{H}_{2} \mathrm{O}, 1: 2\right.$ to $\left.1: 1\right)$ to yield seven subfractions (E9.4.1-E9.4.7). Compound 6 (5.3 mg) was obtained by the separation of Fr. E9.4.3 on a Sephadex LH-20 column ( $\mathrm{MeOH}-\mathrm{H}_{2} \mathrm{O}, 1$ : 2). Compounds 1 (34.2 mg), 2 (21.5 mg), 3 (19.4 $\mathrm{mg})$, and $4(10.0 \mathrm{mg})$ were obtained by the separation of Fr. 
Table 4 Antioxidant activities of the isolated compounds by DPPH radical scavenging assay

\begin{tabular}{lr}
\hline Compound $^{a}$ & $\mathrm{IC}_{50}(\mu \mathrm{M})$ \\
\hline $\mathbf{2}$ & $85.50 \pm 3.08$ \\
$\mathbf{4}$ & $87.21 \pm 1.64$ \\
$\mathbf{5}$ & $49.28 \pm 1.09$ \\
$\mathbf{8}$ & $64.61 \pm 2.99$ \\
$\mathbf{1 3}$ & $16.44 \pm 0.16$ \\
$\mathbf{1 4}$ & $11.22 \pm 0.38$ \\
Ascorbic acid & $12.45 \pm 0.51$ \\
${ }^{a}$ Compounds 1, 3, 6, 7, 9-12, and 15 showed weak or no activities in the \\
DPPH antioxidant assay and ascorbic acid was used as a positive \\
control.
\end{tabular}

E9.4.5 on a $\mathrm{RP}^{-} \mathrm{C}_{18}$ column (acetone- $\mathrm{H}_{2} \mathrm{O}, 1: 4$ to $1: 2.5$ ). Fr. E9.4.6 was subjected to $\mathrm{RP}-\mathrm{C}_{18} \mathrm{CC}$ (acetone- $\mathrm{H}_{2} \mathrm{O}, 1: 2.5$ ) to yield compound 10 (35.9 mg). Fr. E9.5 was separated by $\mathrm{RP}^{-\mathrm{C}_{18} \mathrm{CC}}$ (acetone- $\mathrm{H}_{2} \mathrm{O}, 1: 6$ to $1: 4$ ) to give seven subfractions (E9.5.1E9.5.7). Fr. E9.5.2 was subjected to $\mathrm{RP}^{-\mathrm{C}_{18}} \mathrm{CC}\left(\mathrm{MeOH}-\mathrm{H}_{2} \mathrm{O}\right.$, $1: 3)$ to yield compound $11(3.4 \mathrm{mg})$. Fr. E9.5.6 was subjected to $\mathrm{RP}^{-\mathrm{C}_{18}}$ CC $\left(\mathrm{MeOH}-\mathrm{H}_{2} \mathrm{O}, 1: 1.4\right)$ followed by $\mathrm{RP}^{-\mathrm{C}_{18}} \mathrm{CC}$ (acetone- $\mathrm{H}_{2} \mathrm{O}, 1: 2$ ) to provide compound $12(4.2 \mathrm{mg})$. Fr. E9.5.7 was purified on a $\mathrm{RP}^{-\mathrm{C}_{18}}$ column $\left(\mathrm{MeOH}-\mathrm{H}_{2} \mathrm{O}, 1: 1.5\right)$ to yield compound 15 (7.6 mg). Fr. E10 was separated by silica gel $\mathrm{CC}\left(\mathrm{CHCl}_{3}-\mathrm{MeOH}-\mathrm{H}_{2} \mathrm{O}, 15: 1: 0.05\right.$ to $\left.3: 1: 0.1\right)$ to afford seven subfractions (E10.1-E10.7). Fr. E10.3 was subjected to RP$\mathrm{C}_{18}$ CC (acetone- $\left.\mathrm{H}_{2} \mathrm{O}, 1: 5\right)$ to yield four fractions (E10.3.1-

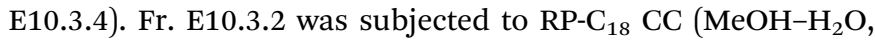
$1: 2.5$ to $1: 1.5)$ to afford eight fractions (E10.3.2.1-E10.3.2.8). Compound $5(7.6 \mathrm{mg})$ was obtained by the separation of Fr. E10.3.2.2 on a RP- $\mathrm{C}_{18}$ column $\left(\mathrm{MeOH}-\mathrm{H}_{2} \mathrm{O}, 1\right.$ : 2). Fr. E10.6 was separated on a silica gel column $\left(\mathrm{CHCl}_{3}-\mathrm{MeOH}-\mathrm{H}_{2} \mathrm{O}, 4: 1\right.$ : 0.1$)$ to yield compound 13 (960.0 mg). Fr. E11 was subjected to silica gel $\mathrm{CC}$ and eluted with a gradient of $\mathrm{CHCl}_{3}-\mathrm{MeOH}-\mathrm{H}_{2} \mathrm{O}$ ( $6: 1: 0.1$ to $2: 1: 0.1$ ) to afford six subfractions (E11.1-E11.6). Fr. E11.4 was further subjected to $\mathrm{RP}^{-\mathrm{C}_{18}} \mathrm{CC}$ (acetone- $\mathrm{H}_{2} \mathrm{O}, 1: 3$ to $1: 2)$ to give compound $14(161.3 \mathrm{mg})$.

Hyperelatoside A (1). Brown amorphous solid; $[\alpha]_{\mathrm{D}}^{20}-38.2(c$ 0.1, MeOH); UV (MeOH) $\lambda_{\max }(\log \varepsilon) 226$ (3.9), 260 (2.4), 292 (2.0) nm; IR (KBr) $\nu_{\max } 3418,2952,1701,1618,1515,1440,1379$, $1273,1209,1076,1028,630 \mathrm{~cm}^{-1} ;{ }^{1} \mathrm{H}$ and ${ }^{13} \mathrm{C}$ NMR data $\left(\mathrm{CD}_{3} \mathrm{OD}\right.$ and DMSO- $d_{6}$ ), see Tables 1 and 2; HRESIMS (positive) $\mathrm{m} / z$ $521.1247[\mathrm{M}+\mathrm{Na}]^{+}$(calcd for $\mathrm{C}_{22} \mathrm{H}_{26} \mathrm{NaO}_{13}, 521.1271$ ).

Hyperelatoside B (2). Brown amorphous solid; $[\alpha]_{\mathrm{D}}^{20}-25.5(c$ 0.1, MeOH); UV (MeOH) $\lambda_{\max }(\log \varepsilon) 225$ (5.4), 260 (1.0) nm; IR $(\mathrm{KBr}) \nu_{\max } 3415,1624,1514,1444,1274,1211,1170,1027$, $630 \mathrm{~cm}^{-1} ;{ }^{1} \mathrm{H}$ and ${ }^{13} \mathrm{C}$ NMR data $\left(\mathrm{CD}_{3} \mathrm{OD}\right)$, see Tables 1 and 2 ; HRESIMS (negative) $m / z \quad 483.1150 \quad[\mathrm{M}-\mathrm{H}]^{-}$(calcd for $\mathrm{C}_{21} \mathrm{H}_{23} \mathrm{O}_{13}$, 483.1139).

Hyperelatoside C (3). Brown amorphous solid; $[\alpha]_{\mathrm{D}}^{20}=-21.2$ (c 0.05, MeOH); UV (MeOH) $\lambda_{\max }(\log \varepsilon) 225$ (5.4), 260 (2.4), 292 (1.0) nm; IR (KBr) $\nu_{\max } 3434,2954,1640,1514,1454,1019$, $661 \mathrm{~cm}^{-1} ;{ }^{1} \mathrm{H}$ and ${ }^{13} \mathrm{C}$ NMR data $\left(\mathrm{CD}_{3} \mathrm{OD}\right)$, see Tables 1 and 2 ; HRESIMS (positive) $m / z$ 489.0998 $[\mathrm{M}+\mathrm{Na}]^{+}$(calcd for $\left.\mathrm{C}_{21} \mathrm{H}_{22} \mathrm{NaO}_{12}, 489.1009\right)$.
Hyperelatoside D (4). Brown amorphous solid; $[\alpha]_{\mathrm{D}}^{20}-44.3(c$ 0.1, MeOH); UV (MeOH) $\lambda_{\max }(\log \varepsilon) 290$ (2.3) nm; IR (KBr) $\nu_{\max }$ 3402, 2950, 2837, 1650, 1455, 1410, 1111, 1022, $671 \mathrm{~cm}^{-1} ;{ }^{1} \mathrm{H}$ and ${ }^{13} \mathrm{C}$ NMR data $\left(\mathrm{CD}_{3} \mathrm{OD}\right.$ and DMSO- $\left.d_{6}\right)$, see Tables 1 and 2 ; HRESIMS (positive) $m / z$ 463.1205 $[\mathrm{M}+\mathrm{Na}]^{+}$(calcd for $\left.\mathrm{C}_{20} \mathrm{H}_{24} \mathrm{NaO}_{11}, 463.1216\right)$.

Hyperelatoside E (5). Brown amorphous solid; $[\alpha]_{\mathrm{D}}^{20}-28.4(c$ 0.02, MeOH); UV (MeOH) $\lambda_{\text {max }}(\log \varepsilon) 290$ (3.0) nm; IR (KBr) $\nu_{\text {max }}$ 3392, 2950, 2836, 1651, 1457, 1411, 1111, 1023, $671 \mathrm{~cm}^{-1} ;{ }^{1} \mathrm{H}$ and ${ }^{13} \mathrm{C}$ NMR data $\left(\mathrm{CD}_{3} \mathrm{OD}\right)$, see Tables 1 and 2; HRESIMS (negative) $\mathrm{m} / \mathrm{z} 439.1247[\mathrm{M}-\mathrm{H}]^{-}$(calcd for $\mathrm{C}_{20} \mathrm{H}_{23} \mathrm{O}_{11}$, 439.1240).

Hyperelatoside F (6). White needles; mp 220-222 ${ }^{\circ} \mathrm{C}$; $[\alpha]_{\mathrm{D}}^{20}-114.3(c 0.05, \mathrm{MeOH}) ; \mathrm{UV}(\mathrm{MeOH}) \lambda_{\max }(\log \varepsilon) 222$ (3.3), 256 (2.9), 319 (3.2) nm; IR (KBr) $\nu_{\max }$ 3439, 2954, 1666, 1626, 1509, 1445, 1366, 1267, 1226, 1062, 694, $652 \mathrm{~cm}^{-1} ;{ }^{1} \mathrm{H}$ and ${ }^{13} \mathrm{C}$ NMR data (DMSO- $d_{6}$ ), see Table 3 ; HRESIMS (positive) $\mathrm{m} / \mathrm{z}$ 383.0946 [M+Na $]^{+}$(calcd for $\mathrm{C}_{15} \mathrm{H}_{20} \mathrm{NaO}_{10}, 383.0954$ ).

\section{Acid hydrolysis}

The absolute configurations of the sugar moieties of 1-6 were determined by the acid hydrolysis method. ${ }^{32}$ Each compound (approximately $1.0 \mathrm{mg}$ ) was separately dissolved in $1 \mathrm{~N} \mathrm{HCl}(0.5$ $\mathrm{mL}$ ), and then heated at $90{ }^{\circ} \mathrm{C}$ in a water bath for $2 \mathrm{~h}$. After extraction with EtOAc two times, the $\mathrm{H}_{2} \mathrm{O}$-soluble fraction was evaporated to dryness under reduced pressure. The residue was dissolved in pyridine $(0.1 \mathrm{~mL})$ containing $\mathrm{L}$-cysteine methyl ester hydrochloride $(0.5 \mathrm{mg})$ and heated at $60{ }^{\circ} \mathrm{C}$ for $1 \mathrm{~h}$. A $100 \mu \mathrm{L}$ solution of $o$-tolylisothiocyanate $(0.5 \mathrm{mg})$ in pyridine was added and the reaction mixture was heated at $60{ }^{\circ} \mathrm{C}$ for $1 \mathrm{~h}$. Then each reaction mixture was analyzed by the Waters 1525 HPLC system using a Waters $2489 \mathrm{UV} / \mathrm{vis}$ detector (at $250 \mathrm{~nm}$ ). Analytical HPLC was performed on the YMC Packed $\mathrm{C}_{18}$ column $(5 \mu \mathrm{m}$, $150 \times 4.6 \mathrm{~mm})$ with a linear gradient elution $\left(\mathrm{CH}_{3} \mathrm{CN}-\mathrm{H}_{2} \mathrm{O}\right.$, $20: 80$ to $40: 60$ ) for $30 \mathrm{~min}$. The derivative of D-glucose was identified in 1-6 by a comparison of the retention time with authentic D-glucose $\left(t_{\mathrm{R}} 16.3 \mathrm{~min}\right)$, which was subjected to the same derivatization procedure.

\section{Measurement of neurite outgrowth}

PC12 cells were purchased from the Cell Bank of Shanghai Institute of Biochemistry and Cell Biology, Chinese Academy of Sciences (Shanghai, China). PC12 cells were maintained in nutrient mixture F-12 medium supplemented with $10 \%$ inactivated $\mathrm{HS}, 5 \%$ inactivated $\mathrm{FBS}$, penicillin $\mathrm{G}\left(100 \mathrm{U} \mathrm{mL}^{-1}\right)$, streptomycin $\left(100 \mu \mathrm{g} \mathrm{mL}^{-1}\right)$, and sodium bicarbonate $\left(2.5 \mathrm{~g} \mathrm{~L}^{-1}\right)$ at $37{ }^{\circ} \mathrm{C}$ in humidified atmosphere of $5 \% \mathrm{CO}_{2}$. Morphological analysis and quantification of neurite-bearing cells were performed using a phase-contrast microscope as previously described. ${ }^{15}$ Briefly, PC12 cells were seeded in poly-L-lysinecoated 24 -well plates at a density of $2 \times 10^{4}$ cells per $\mathrm{mL}$ with normal serum medium for 24 h. The F-12 medium containing low serum ( $2 \% \mathrm{HS}$ and $1 \% \mathrm{FBS}$ ) was replaced prior to exposure to vehicle $(0.1 \% \mathrm{DMSO})$ or indicated reagents. The cells were treated with tested compounds in the presence of NGF $20 \mathrm{ng}$ $\mathrm{mL}^{-1}$ ). Cells without treatment served as a negative control. 
Cells treated with $20 \mathrm{ng} \mathrm{mL}^{-1}$ of NGF served as a positive control. One concentration experiment was repeated in three wells. After an additional $48 \mathrm{~h}$ of incubation, neurite outgrowth of PC12 cells was observed under an inverted microscope using phase-contrast objectives and photographed by the digital camera. Eight images were selected randomly under a microscope for each well. At least 100 cells in each of eight randomly separated fields were scored. The cells with neurites greater than or equal to the length of one cell body were positive for neurite outgrowth and expressed as a percentage of the total cell number in eight fields. Experiments were repeated at least three times, and data are expressed as means \pm standard deviations.

\section{Determination of NO production}

BV-2 microglial cells were purchased from Peking Union Medical College Cell Bank (Beijing, China) and cultured in DMEM supplemented with $10 \%$ heat-inactivated fetal bovine serum, penicillin $\mathrm{G}\left(100 \mathrm{U} \mathrm{mL}^{-1}\right)$, and streptomycin $(100 \mu \mathrm{g}$ $\mathrm{mL}^{-1}$ ) at $37^{\circ} \mathrm{C}$ in a humidified incubator with $5 \% \mathrm{CO}_{2}$. The NO concentration was detected by the Griess reagent. ${ }^{33}$ Quercetin was used as a positive control. BV-2 cells were seeded at the density of $1.5 \times 10^{5}$ cells per $\mathrm{mL}$ in 96-well culture plate and treated with each compound and LPS $\left(1.0 \mu \mathrm{g} \mathrm{mL} \mathrm{mL}^{-1}\right)$ for $24 \mathrm{~h}$. After that, $50 \mu \mathrm{L}$ of cell-free supernatant was allowed to react with an equal volume of Griess reagent (Beyotime Institute of Biotechnology, Shanghai, China) for $15 \mathrm{~min}$ at room temperature in the dark. Then, the absorbance was measured at $540 \mathrm{~nm}$ using a microplate reader. The cell viability of the cultured cells was detected by MTT-based colorimetric method.

\section{Antioxidant activity}

The DPPH radical scavenging assay was performed according to a previously described method. ${ }^{34}$ Ascorbic acid was used as a positive control. The absorbance of the resulting solution of each compound was measured at $517 \mathrm{~nm}$ with a spectrophotometer. Results were expressed as $\mathrm{IC}_{50}$ values.

\section{Conclusions}

In summary, this study is the first report to describe the chemical constituents and their biological activities of $H$. elatoides. Chemical investigation of the aerial parts of $\mathrm{H}$. elatoides led to the isolation of six new phenolic compounds including five unusual biphenyl ether glycosides, hyperelatosides A-E (1-5), and one benzoate glycoside, hyperelatoside F (6). To the best of our knowledge, this represents the first report of the isolation of biphenyl ether glycosides from plants and their putative biosynthetic pathway is proposed. Furthermore, except for $\mathbf{3}$, all the new isolates possessed potent ability to potentiate the activity of NGF to stimulate neurite outgrowth in PC12 cells. Compounds 5 and 8 exhibited moderate anti-neuroinflammatory activities and $\mathbf{1 4}$ showed significant antioxidant activity in vitro. Our findings show that the aerial parts of $H$. elatoides may be an excellent source of neurotrophic phytochemicals for the prevention and treatment of neurodegenerative diseases.

\section{Conflicts of interest}

There are no conflicts to declare.

\section{Acknowledgements}

This work was financially supported by the Scientific Startup Foundation for Doctors of Northwest A\&F University (No. 2452015356) and the Fundamental Research Funds for the Central Universities (No. 2452017173) and the Natural Science Foundation of China (No. 21572182).

\section{Notes and references}

1 (a) C. C. Sánchez-Mateo, B. Prado and R. M. Rabanal, J. Ethnopharmacol., 2002, 79, 119; (b) M. F. Rieli, R. Mattei and C. E. L. de Araujo, Fitoterapia, 2002, 73, 462; (c) A. Viana, J. C. do Rego, G. von Poser, A. Ferraz, A. P. Heckler, J. Costentin and S. M. K. Rates, Neuropharmacology, 2005, 49, 1042; (d) O. Grundmann, Y. Lv, O. Kelber and V. Butterweck, Neuropharmacology, 2010, 58, 767; (e) J. Zhao, W. Liu and J. C. Wang, Chem. Biodiversity, 2015, 12, 309.

2 (a) S. S. Chatterjee, S. K. Bhattacharya, M. Wonnemann, A. Singer and W. E. Müller, Life Sci., 1998, 63, 499; (b) J. Sarris, Phytother. Res., 2007, 21, 703; (c) S. Kasper, F. Caraci, B. Forti, F. Drago and E. Aguglia, Eur. Neuropsychopharmacol., 2010, 20, 747.

3 (a) R. Ciochina and R. B. Grossman, Chem. Rev., 2006, 106, 3963; (b) I. P. Singh and S. B. Bharate, Nat. Prod. Rep., 2006, 23, 558; (c) J. J. Zhang, J. Yang, Y. Liao, X. W. Yang, J. Z. Ma, Q. L. Xiao, L. X. Yang and G. Xu, Org. Lett., 2014, 16, 4912; (d) X. W. Yang, R. B. Grossman and G. Xu, Chem. Rev., 2018, 118, 3508.

4 (a) Z. Q. Yin, Y. Wang, W. C. Ye and S. X. Zhao, Biochem. Syst. Ecol., 2004, 32, 521; (b) N. Tanaka, Y. Kashiwada, S. Y. Kim, M. Sekiya, Y. Ikeshiro and Y. Takaishi, Phytochemistry, 2009, 70, 1456; (c) W. J. Xu, R. J. Li, O. Quasie, M. H. Yang, L. Y. Kong and J. Luo, J. Nat. Prod., 2016, 79, 1971.

5 (a) A. Hecka, B. Maunit, F. Aubriet and J. F. Muller, Rapid Commun. Mass Spectrom., 2009, 23, 885; (b) M. A. Farag and L. A. Wessjohann, Planta Med., 2012, 78, 488; (c) A. Porzel, M. A. Farag, J. Mülbradt and L. A. Wessjohann, Metabolomics, 2014, 10, 574.

6 (a) C. A. Ang'edu, J. Schmidt, A. Porzel, P. Gitu, J. O. Midiwo and G. Adam, Pharmazie, 1999, 54, 235; (b) S. A. F. Tanemossu, K. Franke, N. Arnold, J. Schmidt, H. K. Wabo, P. Tane and L. A. Wessjohann, Phytochemistry, 2014, 105, 171.

7 (a) L. R. Jat, Int. J. Pharm. Pharm. Sci., 2013, 5, 9; (b) Z. B. Zhou, Z. R. Li, X. B. Wang, J. G. Luo and L. Y. Kong, J. Nat. Prod., 2016, 79, 1231.

8 (a) M. A. G. del Rio, M. I. Sanchez-Reus, I. Iglesias, M. A. Pozo, M. Garcia-Arencibia, J. Fernandez-Ruiz, L. Garcia-Garcia, M. Delgado and J. Benedi, CNS Neurol. Disord.: Drug Targets, 2013, 12, 665; (b) D. Zheleva- 
Dimitrova, P. Nedialkov and G. Momekov, Pharmacogn. Mag., 2013, 9, 1.

9 D. Ben-Eliezer and E. Yechiam, Sci. Rep., 2016, 6, 35700.

10 N. Huang, L. Rizshsky, C. Hauck, B. J. Nikolau, P. A. Murphy and D. F. Birt, Phytochemistry, 2011, 72, 2015.

11 L. C. Brito, A. L. R. Berenger and M. R. Figueiredo, Food Chem. Toxicol., 2017, 109, 847.

12 H. Zhu, C. Chen, J. Yang, X. N. Li, J. Liu, B. Sun, S. X. Huang, D. Li, G. Yao, Z. Luo, Y. Li, J. Zhang, Y. Xue and Y. Zhang, Org. Lett., 2014, 16, 6322.

13 H. Jayasuriya, A. M. Clark and J. D. McChesney, J. Nat. Prod., 1991, 54, 1314.

14 (a) P. L. Liu, C. Du, Z. M. Jiang and J. Cai, Xibei Zhiwu Xuebao, 2011, 31, 1268; (b) Q. Sun, P. L. Liu, Q. Zhang, L. X. Cao and Z. M. Jiang, Xibei Zhiwu Xuebao, 2012, 32, 276.

15 (a) X. W. Shi, L. Liu, J. M. Gao and A. L. Zhang, Eur. J. Med. Chem., 2011, 46, 3112; (b) C. C. Zhang, X. Yin, C. Y. Cao, J. Wei, Q. Zhang and J. M. Gao, Bioorg. Med. Chem. Lett., 2015, 25, 5078; (c) R. Bai, C. C. Zhang, X. Yin, J. Wei and J. M. Gao, J. Nat. Prod., 2015, 78, 783; (d) C. C. Zhang, C. Y. Cao, M. Kubo, K. Harada, X. T. Yan, Y. Fukuyama and J. M. Gao, Int. J. Mol. Sci., 2017, 18, 1659.

16 Z. Zhang, H. N. ElSohly, M. R. Jacob, D. S. Pasco, L. A. Walker and A. M. Clark, Planta Med., 2002, 68, 49.

17 N. Tanaka and Y. Takaishi, Phytochemistry, 2006, 67, 2146.

18 M. Iinuma, H. Tosa, T. Ito, T. Tanaka and M. Aqil, Phytochemistry, 1995, 40, 267.

19 S. E. Ukwueze, P. O. Osadebe and F. B. C. Okoye, Nat. Prod. Res., 2015, 29, 1728.

20 Y. L. Huang, C. C. Chen, Y. J. Chen, R. L. Huang and B. J. Shieh, J. Nat. Prod., 2001, 64, 903.

21 G. Bohr, C. Gerhaeuser, J. Knauft, J. Zapp and H. Becker, J. Nat. Prod., 2005, 68, 1545.

22 T. Fukunaga, K. Nishiya, I. Kajikawa, Y. Watanabe, N. Suzuki, K. Takeya and H. Itokawa, Chem. Pharm. Bull., 1988, 36, 1180.

23 K. Yasukawa and M. Takido, Phytochemistry, 1987, 26, 1224.

24 C. Y. Chen, S. L. Hsieh, M. M. Hsieh, S. F. Hsieh and T. J. Hsieh, Chin. Pharm. J., 2004, 56, 141.

25 (a) R. Liu, W. Zhu, Y. Zhang, T. Zhu, H. Liu, Y. Fang and Q. Gu, J. Antibiot., 2006, 59, 362; (b) T. Bunyapaiboonsri, S. Yoiprommarat, K. Intereya and K. Kocharin, Chem. Pharm. Bull., 2007, 55, 304; (c) M. J. Fang, H. Fang, W. J. Li, D. M. Huang, Z. Wu and Y. F. Zhao, Nat. Prod. Res., 2012, 26, 1224; (d) W. Peng, F. You, X. L. Li, M. Jia, C. J. Zheng,
T. Han and L. P. Qin, Zhongguo Tianran Yaowu, 2013, 11, 673; (e) L. L. Xu, C. C. Zhang, X. Y. Zhu, F. Cao and H. J. Zhu, Nat. Prod. Res., 2017, 31, 1875; (f) P. Phainuphong, V. Rukachaisirikul, S. Phongpaichit, S. Preedanon and J. Sakayaroj, Tetrahedron, 2017, 73, 5920.

26 N. Li, H. S. Lee, N. Zhang, Y. N. Sun, J. L. Li, S. S. Xing, J. G. Chen and L. Cui, Phytochem. Lett., 2015, 13, 286.

27 (a) R. F. Curtis, C. H. Hassall, D. W. Jones and T. W. Williams, J. Chem. Soc., 1960, 4838; (b) Z. G. Chen, I. Fujii, Y. Ebizuka and U. Sankawa, Phytochemistry, 1995, 38, 299; (c) K. Huang, I. Fujii, Y. Ebizuka, K. Gomi and U. Sankawa, J. Biol. Chem., 1995, 270, 21495; (d) J. Hargreaves, J. Park, E. L. Ghisalberti, K. Sivasithamparam, B. W. Skelton and A. H. White, J. Nat. Prod., 2002, 65, 7.

28 I. Fujii, Y. Ebizuka and U. Sankawa, J. Biochem., 1988, 103, 878.

29 (a) W. Schmidt and L. Beerhues, FEBS Lett., 1997, 420, 143; (b) M. M. Gaid, D. Sircar, A. Müller, T. Beuerle, B. Liu, L. Ernst, R. Hänsch and L. Beerhues, Plant Physiol., 2012, 160, 1267; (c) I. El-Awaad, M. Bocola, T. Beuerle, B. Liu and L. Beerhues, Nat. Commun., 2016, 7, 11472.

30 (a) W. Schmidt, S. Peters and L. Beerhues, Phytochemistry, 2000, 53, 427; (b) H. R. El-Seedi, M. A. El-Barbary, D. M. H. El-Ghorab, L. Bohlin, A. K. Borg-Karlson, U. Göransson and R. Verpoorte, Curr. Med. Chem., 2010, 17, 854 .

31 (a) P. V. Kiem, N. X. Cuong, N. X. Nhiem, V. K. Thu, N. K. Ban, C. V. Minh, B. H. Tai, T. N. Hai, S. H. Lee, H. D. Jang and Y. H. Kim, Bioorg. Med. Chem. Lett., 2011, 21, 633; (b) X. T. Yan, S. H. Lee, W. Li, Y. N. Sun, S. Y. Yang, H. D. Jang and Y. H. Kim, Food Chem., 2014, 156, 408.

32 T. Tanaka, T. Nakashima, T. Ueda, K. Tomii and I. Kouno, Chem. Pharm. Bull., 2007, 55, 899.

33 (a) Z. Huang, Z. X. Zhu, Y. T. Li, D. R. Pang, J. Zheng, Q. Zhang, Y. F. Zhao, D. Ferreira, J. K. Zjawiony, P. F. Tu and J. Li, J. Nat. Prod., 2015, 78, 2276; (b) J. Li, N. Li, X. Li, G. Chen, C. Wang, B. Lin and Y. Hou, J. Nat. Prod., 2017, 80, 3081; (c) J. Wei, W. H. Guo, C. Y. Cao, R. W. Kou, Y. Z. Xu, M. Górecki, L. D. Bari, G. Pescitelli and J. M. Gao, Sci. Rep., 2018, 8, 2175.

34 (a) O. P. Sharma and T. K. Bhat, Food Chem., 2009, 113, 1202; (b) C. D. Zheng, G. Li, H. Q. Li, X. J. Xu, J. M. Gao and A. L. Zhang, Nat. Prod. Commun., 2010, 5, 1759. 